November 2021

\title{
The influence of intrinsic motivational forces on consumers' product purchase intentions
}

\author{
Sumera Syed \\ Universiti Teknologi Malaysia, sumera0005@gmail.com \\ Syed R. H. Shah \\ The University of the West Indies, srhshah@gmail.com \\ Fauziah S. Ahmad \\ Universiti Teknologi Malaysia, fsa@utm.my
}

Follow this and additional works at: https://digitalcommons.usf.edu/jometr

Part of the Hospitality Administration and Management Commons, and the Marketing Commons

\section{Recommended Citation}

Syed, S., Shah, S. R., \& Ahmad, F. S. (2021). The influence of intrinsic motivational forces on consumers' product purchase intentions. Journal of Mediterranean Tourism Research, 1(2), 70-80.

https://www.doi.org/10.5038/2770-7555.1.2.1006

Corresponding Author

Sumera Syed, House No. 30, Shaheen Block, Sector B-Bahria Town, Lahore-53720 Pakistan

Revisions

Submission date: April. 18, 2021; 1st Revision: April. 22, 2021; Acceptance: November. 03, 2021 


\title{
The Influence of Intrinsic Motivational Forces on Consumers' Product Purchase Intentions
}

\author{
Sumera Syed ${ }^{1}$, Syed Rashid Hussain Shah², and Fauziah Sh. \\ $\mathrm{Ahmad}^{3}$
}

\author{
Azman Hashim International Business School \\ Universiti Teknologi Malaysia, Kuala Lumpur, Malaysia \\ ${ }^{1}$ sumera0005@gmail.com \\ 3fsa@utm.my \\ Faculty of Social Sciences \\ The University of West Indies, St. Augustine, Trinidad and Tobago \\ ${ }^{2}$ srhshah@gmail.com
}

\begin{abstract}
Food is perceived as the top most surviving need of humans since their existence. With the passage of time, this need has been further revolutionized with added requirements of safety and hygienic factors. Halal food having both of these factors, has gained popularity among both Muslims and non-Muslims consumers. Despite of ever increasing trend of Halal food consumption, the research to uncap this amazingly growing sector is still in its infancy stages. Interestingly, the role of intrinsic motivation in shaping up intention of the consumers for Halal food purchase is still not well explored. This study has addressed this untapped area to build better understanding using Self-Determination Theory (SDT), from the domain of psychology which addresses the psychological needs of autonomy, competence and relatedness. SDT in this research with welldesigned conceptual framework tried to highlight the role of intrinsic motivation for Halal food purchase intention. Whereby, the freedom to choose a product is referred as individuals' autonomy, while individuals' knowledge and the capability to buy Halal food product is termed as competence. Whereas, relatedness precisely talks about the social bonding of individuals through having better feelings and care for others in any environmental setting. Henceforth, first time ever, SDT has been used to explore the impact of intrinsic motivation on Halal food purchase intentions, whereby anatomy, competence, and relatedness is thoroughly providing an opportunity to analyze the shaped up individuals' intentions and behaviors, respectively. Lastly, the important implications and future recommendations are also discussed in this study.
\end{abstract}

Keywords: halal food purchase intention, autonomy, competence, relatedness, selfdetermination theory, intrinsic motivation

\section{Introduction}

The last decade termed as one of the most growing for Halal food sector in the food industry (Thomson Reuters, 2018). It has become a choice of many irrespective of their religion and following for any particular school of thought (Ali et al., 2017). Some are choosing Halal food solely because of their religious obligations; while others prefer Halal food primarily due to the reason of its significant association with safety, hygiene, and quality (Ali et al., 2017; Wibowo \& 
Ahmad, 2016). Despite the fact that this is one of the most popular area of research in the food sector, the researchers have conducted most of the studies on understanding the Halal food purchase intentions through extrinsically motivated factors, either by using Theory of Reasoned Action (TRA) or Theory of Planned Behavior (TPB), Khan et al. (2017) interestingly the intrinsically motivated factors get washed out from the eyes of the researcher due to a sole focus on extrinsically motivated factors to understand the purchase intentions and behaviors of the consumers for Halal food.

Ryan \& Deci $(2017$; 2019) promotes significantly that for an individual to be intrinsically motivated there isn't any external influences, therefore the acts resulted out of intrinsic motivation seem to be lasting for longer periods. Whereas, the behaviors those shaped up due to externally motivated factors may get change, as soon the external situation of an individual is changed. This raises the need to have a deeper and better understanding of both intrinsic and extrinsic factors to clearly identify the impact of each on the intentions and behaviors of the consumers. (Widyarini \& Gunawan, 2018). However, the individuals' basic psychological need fulfillment is mainly dependent on the level of satisfaction that is to be attained through the role played by the level of individuals' autonomy, competence, and relatedness (Wang et al., 2019). Understanding the dearth of knowledge in this particular area, this study, therefore, focuses to develop a better conceptual understanding about the expected behaviors of intrinsically motivated individuals particularly for Halal food purchase intentions. Moreover, the domain remains to be a psychological ground, in which SDT resonate highly within its three distinctively factors autonomy, competence and relatedness.

SDT presented by Deci \& Ryan (1985) discussed that basic innate needs of individuals are equally important not only to survive but also play a significant role in the development of individuals' personality as well. In SDT theory, the factor autonomy addresses to the self-deciding behavior of an individual without having any external factors to be involved into it (Ntoumanis et al., 2020); the second factor of SDT theory competence describes the one's understanding that is built through the acquired knowledge and the ability to execute the possessed knowledge (Zsóka et al., 2013); whereas, the third factor relatedness highlights the social bonding of an individual that primarily resulted into developing a care feeling and shaping up of individual connectedness with others in a given environmental setting (Martela \& Riekki, 2018).

The eating behaviors had been analyzed by some researchers while using a SDT as a grounded theory (Teixeira et al., 2011; Verstuyf et al., 2012) but the studies that highlight the role of SDT in shaping up individuals' intentions for Halal food purchase, are non-existent. Therefore, this study is presumed to be the first one that has mainly underlined the role of SDT in building better understanding about the individuals' purchase intentions for Halal food products.

\section{Literature Review}

\section{Halal Food as a Driving Force}

Whatever act allowed to its followers in Islam is termed as Halal (El-Seidi, 2018; Fuseini et al., 2016). The other synonym in Arabic language for Halal is the word 'thayyib' that associates with safety, healthy, and cleanliness factors (Ansawi et al., 2018). The followers of Islam are always instructed to consume only Halal products and discouraged towards non-Halal products (Azam, 
2016). Therefore, Muslims urge to make a use of only Halal food products and must see it as an integral part of their every day's life, as this is categorically ruled in their holy book Quran and distinguished very clearly between the Halal (allowed) and Haram (prohibited) to its followers (Abdullah et al., 2019; Baharuddin et al., 2015).

Undoubtedly, a religious obligation for Muslims to consume only Halal food products has transformed the basic psychological need into a thriving force of self-satisfaction, resulted grossly as a growth of Halal food businesses (Afendi et al., 2014). It is also noted that Muslims commonly avoid the food that lacks authenticity as part of its certification to highlight the credibility of consuming such products termed Halal for them, Sadek (2001). However, at times in case of certification absence, the Muslims usually try to seek the permission to consume food products, while examining the ingredients as labeled on the product (Al-Harran \& Low, 2008). The healthrelated benefits such as safety, quality, and cleanliness, which marked the food as Halal for Muslims has also played an instrumental role for non-Muslims as well, in adopting the practice to consume more Halal food products (Mathew et al., 2014; Wibowo \& Ahmad, 2016; Bogan \& Arica, 2019).

\section{Theoretical Background}

Mostly it is either a TRA or the TPB that is commonly referred by the researchers while examining the Halal food consumption patterns (Ansawi et al., 2018; Khan et al., 2017). Interestingly, the researchers also agree that both of these theories do significantly lack the potential to address the underlying phenomena of explaining the individuals' intentional thoughts, those are created and resided primarily due to their intrinsic motivation (Ansawi et al., 2018; Rise et al., 2010). Moreover, TPB, as an extension of TRA illustrates the behaviors those are generally resulted because of extrinsically motivated factors, remain to show the highly inconsistent individuals' behaviors and a lack of predictability for their intentions, also TRA fails to identify the driving factors of such behaviors to an extent (Gilal et al., 2019; Hagger \& Chatzisarantis, 2009; Leavell, 2017).

Armitage \& Conner (2010) examined the capability of TPB in generalizing the understanding about the freely performed actions or under certain pressures. Lately, the researchers get agreed that both extrinsic and intrinsic factors should be considered and treated importantly, while studying the individuals' intent to make any purchase decision (Gilal et al., 2019; Widyarini \& Gunawan, 2018). This highlights the importance of using a theory that has a propensity to explain the underlying assumptions of purchasing Halal food products primarily triggered due to internal motives of individuals, better than other theories those are only divulging a certain aspect of externally influenced phenomena for any purchase behavior. Gilal et al. (2019) advocated the usage of SDT for building better understanding, mainly as it dealt exactly while evoking a certain set of urge among individuals to satisfy the basic fulfillment need of selecting a food having internally triggered source generated from the autonomy, competence and relatedness factors. Humans are naturally inclined and motivated to perform certain behaviors that lead towards their betterment and growth, SDT theory termed as meta-theory in understanding and conceptualizing certain internally motivation factors (Deci and Ryan, 1985).

Researchers in the past have discussed the effects of intrinsically motivated behaviors along with the absence of such. They concluded that autonomy, competence and relatedness play a vital role 
in the development of individuals' growth and well-being, however the absence of such leaves irreparable marks on the personality of the individuals (Kinnafick et al., 2016; Ntoumanis et al., 2020). Moreover, the more satisfying purchase decisions are mainly due to the internally triggered factors those contribute significantly in creating associations of individuals' decision making with their emotions (Gilal et al., 2019; Loroz \& Braig, 2015; Thomson, 2006). Therefore, it is strongly suggested to use the SDT theory, while analyzing the individuals' purchase behaviors that may generate interesting insights those highlighting the primary drivers, which encourage individuals to make Halal food purchase decisions (Al-Jubari, et al., 2019; Luqman et al., 2018).

\section{Autonomy}

The decisions those are made without having any external influences on a choice of individual's and reflect one's satisfaction referred as autonomy (Deci \& Ryan, 2000; Teixeira et al., 2011). Therefore, the individuals' interest to exert a certain behavior that ultimately leads to the selfdetermination, is fairly represented by autonomy (Chen et al., 2019). Despite having a clear concept distinction between independence and autonomy, many people uses them interchangeably (Markus et al., 1996; Ryan \& Connell, 1989). There is a possibility that the individuals despite being autonomous still may depend on others to execute the actions, as per their own will. This includes certain suggestions or use of experience of others to attain the self-satisfaction while growing individuals' own personality and wellbeing (Chirkov et al., 2008; Ryan \& Lynch, 1989).

Contrary to that, some people would not be able to make certain decisions, despite showing their independence (Deci \& Ryan, 2008). Nonetheless, it is evidently proven that the consumers are encouraged to make certain purchases primarily due to a reason of having a feel of exercising the power, they possess Gilal et al. (2019). Moreover, André et al. (2018) studied consumers, whose welfare reported to be heavily devastated, due to a dissatisfaction feel of their autonomy. Hence, a positively dependent relationship exists between one's autonomous motivation and eating behavior i.e. emotional eating and eating self-efficacy (Andrade et al., 2010; Mata et al., 2009).

Like other religions, Muslims consumers seem to be influenced by their religious obligations while making purchase decisions as defined by in Islamic dietary laws (Ali et al., 2017; Blackwell et al., 2001; Power, 2009; Razzaque \& Chaudhry, 2013). Therefore, the consumers tend to show a highest level of satisfaction which resulted out of a purchase decision made strictly under the religious obligations. Hence, the Halal food products purchases made as per the individuals freedom result in consumers' satisfaction because they felt abide by the restrictions, imposed by the religion. Therefore, based on the above discussion, the proposition is formulated as:

- P1: Consumers' autonomy carrying a sense of religious obligations has a positive influence on shaping up the purchase intention of consumers for Halal food products.

\section{Competence}

The sense of having a pride and confidence feel by the consumers, which is knitted tightly with one's skill development and ability to gain a particular knowledge about the surroundings, is referred as competence (Gonczi \& Hager, 2010; Legault, 2017; Ryan \& Powelson, 1991; White, 1960). Wang et al. (2019) elaborated deeply on individuals' competence level by describing it as a sense to achieve the expected outcome. Martela \& Riekki (2018) discuss that individuals' 
satisfaction and well-being is an outcome of the impacted environment. Hence it is incited due to the certain level of competence which enables an individual to act accordingly and in an eloquent manner that turns out as a positive charge in the environment, subsequently (Legault, 2017).

Moreover, Gilal et al. (2019) studied that consumers' urge to attain and exercising a certain level of control over their acts that describe their capability to perform the task efficiently, may have a strong influence on their intentions to make a purchase decision. Amenuvor et al. (2019) argued that the competence influences the purchase behaviors significantly. Furthermore, lot of researches show that the competence is having a relationship with one's possessed knowledge and the respective purchase intentions (Awan et al., 2015; Aziz \& Chok, 2013). Based on the above discussion, following proposition is developed as:

- P2: Halal food products purchase intentions are positively influenced by the Consumers' competence

\section{Relatedness}

The term relatedness described as the connectivity of an individual with others in a community by having a feel of care and entrusted relationship (Ryan \& Deci, 2000). Lambert et al. (2010) debated that a meaningful life is primarily due to the connectedness and familial bond. Deci and Ryan (2014) studied the one's sense of belongingness and a communal bond in relationship with need fulfillment of being there for others, as it satisfies the individuals' need of self-well-being. It is a basic need of humans to belong to group of other humans through building certain relationships, as this signaled their social acceptance by others that eventually satisfies their mental health (Calp, 2020).

Otherwise, they feel isolated and alone, in case such sense of belongingness is missing (DeHaan et al., 2016). Amenuvor et al. (2019) discussed the green purchase behavior of consumer which, however, shows a negative effect of the relatedness on purchase behaviors. Ali (2017) identifies that the perception of others on individuals well-being and social connectedness may affect the purchase behaviors of individuals. Hence, above stated discussion generates the following proposition:

- P3: Individuals purchase intentions for Halal food products are influenced positively by relatedness.

\section{Conceptual Framework}

Based on the above discussion of literature, the proposed conceptual framework of the study has been depicted in Figure 1. The conceptual framework illustrates the direct influence of basic psychological needs of autonomy, competence and relatedness (which are acting as independent variables) on Halal food purchase intention (which has been taken as a dependent variable). 
Figure1: Proposed framework to examine the relationship between basic psychological needs and Halal food purchase intention

\section{Basic Psychological Needs}

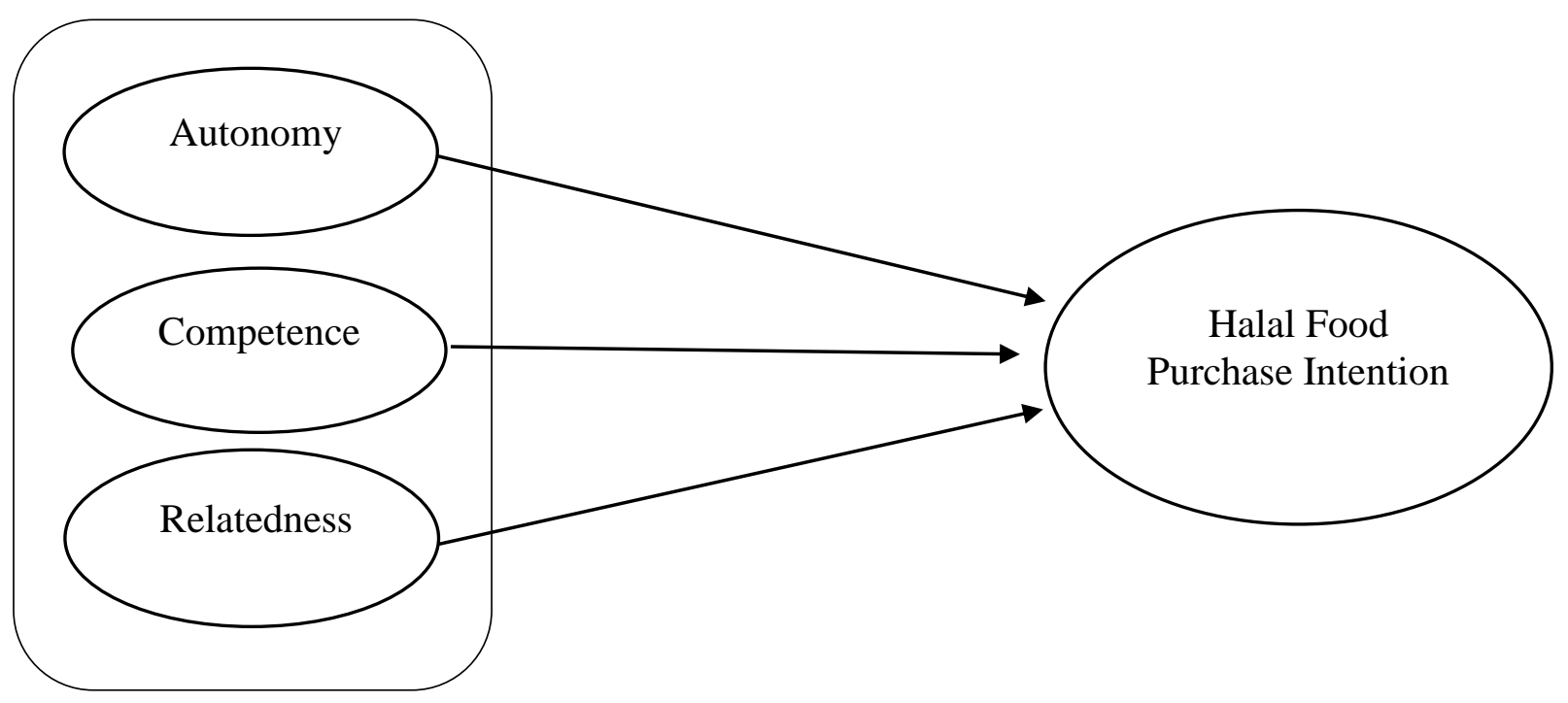

\section{Conclusion}

Many believe that building an understanding about consumer purchase intentions and behaviors are easy process. However, the researchers discussed and highlighted the importance of building deep understanding about consumers, who are living under different societal settings. The significant number of researchers strongly debated the role of multiple factors those eventually influence the purchase decisions. These influences seem to show a significant effect on both individual and collective level. Consumers are vulnerable to external forces that keep exerting certain force on them to make the decisions, which probably they might had not taken. Interestingly, recent studies show that whatever amount of external pressure is exerted on consumers for having forceful and undesirable decisions, still the knowledge base of consumers plays a significant role in decision making. Such knowledge is gained from many sources and embedded into the decisive mind of the knowledgeable consumer. Evidences are brought into limelight, where the intrinsically evoked factors have started playing more dominant role than extrinsic motivations. Conclusively, researchers get agreed that these days most of the purchase intentions of consumers are driven by three main factors competence, autonomy and relatedness.

Eventually, the decisions those are being made due to the influence of these factors are more selfsatisfying sustainable. The higher the autonomous level of the consumers in respect to decisions making, the better the sense of one's need fulfillments. Moreover, the consumers who show greater tendency to withstand the external pressures and influences also seen as most satisfying, as they are primarily focused on their very own basic need fulfillment. Besides, the knowledge of consumer about any product for which they are making purchase decisions also tends to be resulted into the mere satisfaction, because they have built certain set of skills and thereby enhance their abilities to rationalize their own purchase decisions, solely based on intrinsic motivation. Therefore, the element of competence serves as a change agent for having better decision behaviors by the consumers. There is absolutely no denial from the importance of connectedness, as this 
ensures better decision making, while considering the social connectivity and bonding with others in a given environment. Humans tend to behave in a way that is not only socially acceptable but also give them a certain sense of association and belongingness with any particular group. Hence, the element of care encompasses the entire relationship phenomena- particularly when we deal with the people who are alike us. Whatever decision one's make, it tends to have a specific impact on those, whom the individual cares about. This social connectivity is not mainly driven by any external factors but primarily due to the intrinsically motivated factors. Hence, this research purposely explored the decision making criteria for those who are more socially responsible, yet internally motivated though. Successively, the notion leads to the most satisfying mind set, reflecting high sense of connectivity that is reasoned due to the decisions made based on valued relationship. Convincingly the significant impact of "autonomy, "competence", and "relatedness" seem to be reflected in every decision behaviors of individuals, who are highly motivated and driven by their intrinsic set of factors. Undoubtedly, the exploration of intrinsically driven factors in relationship with purchase behavior intentions have distinctively highlighted the importance of using the SDT theory, while creating more meaningful and logical understanding, as well as justification of individuals' actions, those are primarily driven from the inner SDT factors, hence resulted into better fulfillment of the individuals' need.

\section{Managerial Implications}

In a case of today's savvy consumer- who exercises a power to decide about the purchases, who possesses a knowledge to stand next to the purchase decisions, who believes that the decisions made are exerting a significant impact on the people those are connected due to a social bond, represented heavily with the feeling of care towards each other. Since all these factors are attributed to the SDT theory- hence, the researchers are largely agreed that the intrinsic motivation is predominantly impacting the individuals' intention to make a product purchase decision. Moreover, the one's belief on his own capability to make a decision that fully satisfies the need hence result into the expected purchase decision is attributed with intrinsic motivation. However, it further translated into the feel of empowerment for making the purchase decisions on one's own, enhances a contended level of consumer satisfaction. Despite having all the freedom and knowledge to exercise a certain purchase behavior, the most meaningful will be the social connectedness of consumers. The given notion has significantly strengthened in the recent past that the service providers feeling themselves compelled to make their offerings in line with those that make the consumers more intrinsically satisfied, whereby the marketing moves has been shifted from representing merely the product functional attributes to more of highlighting the sense of one's own pride and empowerment that primarily triggered through the intrinsic motivation, while exercising the product purchase behaviors. It is momentously demanded from today's organizations to have the strategies those are in line with meeting consumers' basic psychological needs; those resonated well with the intrinsic motivational forces. The services and product offerings should be designed in a way that it offers more privileges and sense of achievement to the consumer, who is instinctively motivated by the intrinsic factors. Moreover, it is generally agreed that today's consumer demand has created a major shift for marketers from the obsolescent conventional product offering practices to more of consumer centric services. The competition is fierce, now it is more than just fulfilling the basic consumer needs of consumers. Those who want to create a distinction in their services and product offerings must focus to address the highly important intrinsic forces of individuals, as defined through SDT. This has further leveraged an 
idea of highlighting the connectedness factor among consumers, as this would result into a successful enhancement of the sense of consumers' need fulfillment.

\section{Recommendations for Future Research}

Everyday social scientists are engaged in exploring the new avenues for building better understanding of the customers, those relying heavily on the hidden set of needs. These days the technological spectrum is well entrusted among the businesses and proven to have a significant impact on organizational performances, indeed it is not only limited to provide only better services but also serves as a ray of hope for organizations to stay ahead and be a market leader. Importantly, the organizations must strive hard and be persistent in their approach to explore more about the customers purchase intentions and decision making processes, while using multiple and different subject approaches. Since Halal food research is predominant with more conventional approaches and methods, therefore it is pertinent to highlight the importance of using different and new theoretical frameworks from multiple subject domains in combination of marketing theories and concepts along with advance quantifiable measure and techniques to study the effective knowledge about customer's purchase intention, especially for Halal Food.

\section{References}

Abdullah, F., Borilova, G., \& Steinhauserova, I. (2019). Halal criteria versus conventional slaughter technology. Animals: An open access journal from MDPI, 9(8), 530. https://doi.org/10.3390/ani9080530.

Ali, A. (2017). Halal products purchase intention in Pakistan: Evidences from non-Muslim community. Arabian Journal of Business Management Review, 7(4), 1-6.

Afendi, N. A., Azizan, F. L., \& Darami, A. I. (2014). Determinants of halal purchase intention: Case in Perlis. International Journal of Business and Social Research, 4(5), 118-123.

Al-Harran, S. \& Low, P. (2008). Marketing of halal products: The way forward. The Halal Journal. 44-46 http://www.halaljournal.com.

Ali, A., Ali, A., Xiaoling, G., Sherwani, M., \& Hussain, S. (2017). Expanding the theory of planned behaviour to predict Chinese Muslims halal meat purchase intention. British Food Journal, 120(1), 2-17.

Al-Jubari, I., Mosbah, A., \& Talib, Z. (2019). Do intrinsic and extrinsic motivation relate to entrepreneurial intention differently? A self-determination theory perspective. Academy of Entrepreneurship Journal, 25(2), 1-14.

Amenuvor, F. E., Owusu-Antwi, K., Seong-Chan, B., Shin, S. K. S., \& Basilisco, R. (2019) Green purchase behavior: The predictive roles of consumer self-determination, perceived customer effectiveness and perceived price. International Journal of Scientific Research and Management, 7(10). https://doi.org/10.18535/ijsrm/v7i10.em05.

Andrade, A. M., Coutinho, S. R., Silva, M. N., Mata, J., Vieira, P. N., Minderico, C. S., Melanson, K. J., Baptista, F., Sardinha, L. B., \& Teixeira, P. J. (2010). The effect of physical activity on weight loss is mediated by eating self-regulation. Patient Education and Counseling 79, 320-326, https://doi:10.1016/j.pec.2010.01.006.

André, Q., Carmon, Z., Wertenbroch, K., Crum, A., Frank, D., Goldstein, W., Huber, J., Van Boven, L., Weber, B., \& Yang, H. (2018). Consumer choice and autonomy in the age of artificial intelligence and big data. Customer Needs and Solutions, 5, 28-37. https://doi.org/10.1007/s40547-017-0085-8.

Ansawi, N., Sukoco, B. M., \& Fanani, M. A. (2018). Halal products consumption in international chain restaurants among global Moslem consumers., International Journal of Emerging Markets, 13(5), 1273-1290. https://doi.org/10.1108/IJoEM-11-2017-0495.

Armitage, C. J., \& Conner, M. T. (2010). Efficacy of the theory of planned behaviour: A meta-analytic review. British Journal of Social Psychology, 40(4), 471-499. https://doi.org/10.1348/014466601164939.

Awan, H. M., Siddiquei, A. N., \& Haider, Z. (2015). Factors affecting Halal purchase intention-evidence from Pakistan's Halal food sector. Management Research Review, 38(6), 640-660. https://doi.org/10.1108/MRR-01-2014-0022. 
Azam, A. (2016). An empirical study on non-Muslim's packaged halal food manufacturers: Saudi Arabian consumers' purchase intention. Journal of Islamic Marketing, 7(4), 441-460. https://doi.org/10.1108/JIMA12-2014-0084.

Aziz, Y.A., \& Chok, N.V. (2013). The role of halal awareness, halal certification, and marketing components in determining halal purchase intention among non-Muslims in Malaysia: A structural equation modeling approach. Journal of International Food \& Agribusiness Marketing, 25(1), 1-23.

Baharuddin, K., Kassim, N. A., Nordin, S. K., \& Buyong, S. Z. (2015). Understanding the halal concept and the importance of information on halal food business needed by potential Malaysian entrepreneurs. International Journal of Academic Research in Business and Social Sciences, 5(2), 170-180.

Blackwell, R.D., Miniard, P.W., \& Engel, J.F. (2001), Consumer Behavior. Harcourt Inc.

Boğan, E. \& Arıca, R. (2019). Müslüman-dostu otel müşterilerinin helal konsepte ilişkin memnuniyet ve şikâyetleri: Alanya örneği. In Second International Halal Tourism Congress Proceedings Book (pp. 259-268), Alanya/Turkey.

Calp, S. (2020). I belong to this world! A teacher practice for developing relatedness in the school environment. European Journal of Education Studies, 7(1), 22-40. http://doi.org/10.5281/zenodo.3694140.

Chen, X., Fang, S., Li, Y., \& Wang, H. (2019). Does identification influence continuous e-commerce consumption? The mediating role of intrinsic motivations. Sustainability, 11(7), 1-20.

Chirkov, V. I. (2008). Culture, personal autonomy and individualism: Their relationships and implications for personal growth and well-being, Perspectives and progress in contemporary cross-cultural psychology. Scholarworks. https://scholarworks.gvsu.edu/iaccp_papers/10/.

Deci, E. L., \& Ryan, R. M. (1985). Intrinsic motivation and self-determination in human behavior. Plenum.

Deci, E. L., \& Ryan, R. M. (2008). Self-determination theory: A macrotheory of human motivation, development, and health. Canadian Psychological Association, 49(3), 182-185.

DeHaan, C. R., Hirai, T., \& Ryan, R. M. (2016). Nussbaum's capabilities and self-determination theory's basic psychological needs: Relating some fundamentals of human wellness. Journal of Happiness Studies, 17(5), 2037-2049. https://doi.org/10.1007/s10902-015-9684-y.

El-Seidi, R. I. (2018). Determinants of halal purchasing intentions: Evidences from UK. Journal of Islamic Marketing, 9(1), 167-190. https://doi.org/10.1108/JIMA-02-2016-0013.

Fuseini, A., Knowles, T. G., Hadley, P. J., \& Wotton, S. B. (2016). Halal stunning and slaughter: Criteria for the assessment of dead animals. Meat Science, 119, 132-137. https://doi.org/10.1016/j.meatsci.2016.04.033.

Gilal, F. G., Zhang, J., Paul, J., \& Gilal, N. G. (2019). The role of self-determination theory in marketing science: An integrative review and agenda for research. European Management Journal, 37, 29-44.

Gonczi, A., \& Hager, P. (2010). The competency model, In P Peterson, E Baker \& B McGaw (Eds.), International Encyclopedia of Education (403-410). Elsevier.

Hagger, M. S., \& Chatzisarantis, N. (2009). Integrating the theory of planned behaviour and self-determination theory in health behaviour: a meta-analysis. Journal of Health and Psychology, 14(2), 275-302.

Khan, M. M., Asad, H., \& Mehboob, I. (2017). Investigating the consumer behavior for halal endorsed products: Case of an emerging muslim market. Journal of Islamic Marketing, 8(4), 625-641. https://doi.org/10.1108/JIMA-09-2015-0068.

Kinnafick, F.E., Thøgersen-Ntoumani, C., \& Duda, J. (2016). The effect of need supportive text messages on motivation and physical activity behaviour. Journal of Behavioral Medicine, 39, 574-586. https://doi.org/10.1007/s10865-016-9722-1.

Lambert, N. M., Stillman, T. F., Baumeister, R. F., Fincham, F. D., Hicks, J. A., \& Graham, S. M. (2010). Family as a salient source of meaning in young adulthood. The Journal of Positive Psychology, 5(5), 367-376.

Leavell, J. P. (2017). Controlling and informational planned behavior: Self-determination theory and the theory of planned behavior. Atlantic Marketing Journal, 5(3), 81-91.

Legault, L. (2017). The need for competence. Encyclopedia of Personality and Individual Differences. http://doi.org/10.1007/978-3-319-28099-8_1123-1.

Loroz, P. S., \& Braig, B. M. (2015). Consumer attachments to human brands: The "oprah effect". Psychology and Marketing, 32(7), 751-763.

Luqman, A., Masood, A. \& Ali, A. (2018). An SDT and TPB-based integrated approach to explore the role of autonomous and controlled motivations in SNS discontinuance intention, Computers in Human Behavior 85, 298-307. http://doi .org10.1016/j.chb.2018.04.016.

Markus, H. R., Kitayama, S., \& Heiman, R. J. (1996). Culture and basic psychological principles. In E. T. Higgins \& A. W. Kruglanski (Eds.), Social psychology: Handbook of basic principles (pp. 857-913). Guilford Press. 
Martela, F., \& Riekki, T. (2018). Autonomy, competence, relatedness, and beneficence: A multicultural comparison of the four pathways to meaningful work. Frontiers in psychology, 9, 1-14 https://doi.org/10.3389/fpsyg.2018.01157.

Mata, J., Silva, M. N., Vieira, P. N., Carraça, E. V., Andrade, A. M., Coutinho, S. R., Sardinha, L.B., \& Teixeira, P.J. (2009). Motivational "spill-over" during weight control: Increased self-determination and exercise intrinsic motivation predict eating self-regulation. Health Psychology,28, 709716. https://doi.org/10.1037/a0016764

Mathew, V. N., Abdullah, A. M. R. A., \& Ismail, S. N. M. (2014). Acceptance on halal food among non-muslim consumers. Procedia - Social and Behavioral Sciences, 121, 262-271.

Ntoumanis, N., Ng, J. Y.Y., Prestwich, A., Quested, E., Hancox, J. E., Thøgersen-Ntoumani, C., Deci, E. L., Ryan, R. M., Lonsdale, C., \& Williams, G. C. (2020). A meta-analysis of self-determination theory-informed intervention studies in the health domain: Effects on motivation, health behavior, physical, and psychological health. Health Psychology Review. https://doi.org/10.1080/17437199.2020.1718529

Power, C. (2009, May 14). Halal: Buying Muslim. Time Magazine.

Razzaque, M. A., \& Chaudhry, S. N. (2013). Religiosity and muslim consumers' decision-making process in a nonmuslim society. Journal of Islamic Marketing, 4(2), 198-217.

Rise, J., Sheeran, P., \& Hukkelberg, S. S. (2010). The role of self-identity in the theory of planned behavior: A metaanalysis. Journal of Applied Social Psychology, 40(5), 1085-1105. https://doi.org/10.1111/j.15591816.2010.00611.x

Ryan, R. M., \& Connell, J. P. (1989). Perceived locus of causality and internalization: Examining reasons for acting in two domains. Journal of Personality and Social Psychology, 57(5), 749-761. http://dx.doi.org/10.1037/0022-3514.57.5.749.

Ryan, R. M., \& Deci, E. L. (2000). Self-determination theory and the facilitation of intrinsic motivation, social development, and well-being. American Psychologist, 55(1), 68-78. https://dx.doi.org/10.1037/0003066X.55.1.68.

Ryan, R. M., \& Deci, E. L. (2017). Self-determination theory: Basic psychological needs in motivation, development, and wellness. Guilford Press.

Ryan, R. M. \& Deci, E. L. (2019). Chapter four - Brick by Brick: The origins, development, and future of selfdetermination theory. Advances in Motivation Science, 6, 111-156. https://doi.org/10.1016/bs.adms.2019.01.001.

Ryan, R. M., \& Lynch, J. H. (1989). Emotional autonomy versus detachment: revisiting the vicissitudes of adolescence and young adulthood. Child Development, 60(2), 340-356. https://doi.org 10.1111/j.14678624.1989.tb02720.x.

Ryan, R. M., \& Powelson, C. L. (1991). Autonomy and relatedness as fundamental to motivation and education. Journal of Experimental Education, 60(1), 49-66. http://dx.doi.org/10.1080/00220973.1991.10806579

Sadek, M. (2001). The Halal Food Industry in the Face of Globalization. Paper presented at the First Meeting of Halal Food Council, Bali, Indonesia.

Teixeira, P. J., Patrick, H., \& Mata, J. (2011). Why we eat what we eat: the role of autonomous motivation in eating behaviour regulation. Nutrition Bulletin, 36(1), 102-107. https://doi.org/10.1111/j.14673010.2010.01876.x.

Thomson, M. (2006). Human brands: Investigating antecedents to consumers' strong attachments to celebrities. Journal of Marketing, 70(3), 104-119.

Thomson Reuters (2018). Global Halal Food Consumption Market Report 2018-2023. Orbisresearch. http://www.orbisresearch.com/reports/index/2018-2023-global-halal-food-consumption-market-report.

Verstuyf, J., Patrick, H., Vansteenkiste, M., \& Teixeira, P. J. (2012). Motivational dynamics of eating regulation: a self-determination theory perspective. International Journal of Behavioral Nutrition and Physical Activity, 9(21). https://doi.org.10.1186/1479-5868-9-21.

Wang, C. K. J., Liu, W. C., Kee, Y. H., \& Chian, L. K. (2019). Competence, autonomy, and relatedness in the classroom: understanding students' motivational processes using the self-determination theory. Heliyon, 5(7), 1-16. https://doi.org/10.1016/j.heliyon.2019.e01983.

White, R. W. (1960). Competence and the psychosexual stages of development. In M. R. Jones (Eds.), Nebraska symposium on motivation, (97-141). University of Nebraska Press.

Wibowo, M. W., \& Ahmad, F. S. (2016). Non-muslim consumers' halal food product acceptance model. Procedia Economics and Finance, 37(16), 276-283. 
Widyarini, L. A., \& Gunawan, S. (2018). Predicting consumer purchase intention on fashion products in online retailer: Integration of self-determination theory and theory of planned behavior. International Journal of Emerging Research in Management \& Technology, 6(9), 7-18.

Zsóka, Á., Szerényi, Z., Széchy, A., \& Kocsis, T. (2013). Greening due to environmental education? Environmental knowledge, attitudes, consumer behavior and everyday pro-environmental activities of Hungarian high school and university students. Journal of Cleaner Production, 48, 126-138.

https://doi.org 10.1016/j.jclepro.2012.11.030. 